Pengaruh Penggunaan Media Gambar Untuk Meningkatkan Hasil Belajar Bahasa Arab

\title{
Pengaruh Penggunaan Media Gambar Untuk Meningkatkan Hasil Belajar Bahasa Arab Siswa Kelas VII Di Madrasah Tsanawiyah Muhammadiyah 12 Palirangan
}

\section{Idzi’ Layyinati}

Sekolah Tinggi Ilmu Tarbiyah Muhammadiyah Paciran Lamongan, Indonesia

\begin{abstract}
Education is a necessity for everyone. Educational activities are activities that are very important in human life and cannot be separated from their lives. With education, human needs regarding change and development can be fulfilled. The mean score of the pre-test results was 71.73, while the mean value of the post-test results was 79.61. From these data it can be seen that the pre-test result value is lower than the post-test score, so it can be interpreted that there are differences in student learning outcomes before and after using image media in the learning process. the completeness of the pre-test result value is $46.15 \%$, while the post-test result value is $80.76 \%$. From this data, it can be seen that using image media can affect student learning outcomes. Then from the hypothesis testing using the Product Moment Correlation test and the Paired Sample T-test with the help of SPSS 20 software in the sig (2-tailed) section, it is known that $0.000<0.05$ The condition is if $r$ count is smaller than $r$ table, then HO is accepted. and $\mathrm{Ha}$ is rejected and vice versa if $r$ count is greater than $r$ table ( $r$ count $>r$ table) then HO is rejected and $\mathrm{Ha}$ is accepted. In fact, $r$ count (0.977) is greater than $r$ table (0.404). Thus HO is rejected and $\mathrm{Ha}$ is accepted. As the basis for decision making in the Product Moment Correlation test and decision guidelines based on the probability value, it can be concluded that $\mathrm{HO}$ is rejected and $\mathrm{Ha}$ is accepted. This means that image media can affect the improvement of learning outcomes in Arabic language material for class VII at MTs. Muhammadiyah 12 Palirangan
\end{abstract}

Keywords: Image Media, Learning outcomes

\section{Pendahuluan}

Pendidikan merupakan kebutuhan bagi semua orang. Kegiatan pendidikan merupakan kegiatan yang sangat penting dalam kehidupan manusia dan tidak dapat dipisahkan dari kehidupannya. Dengan pendidikan, kebutuhan manusia mengenai perubahan dan perkembangan dapat terpenuhi.

Bahasa sebagai alat komunikasi memiliki fungsi yang sangat penting dalam kehidupan yaitu sebagai media untuk menyampaikan pesan. Dengan bahasa manusia dapat mengungkapkan semua perasaannya baik berupa ucapan, isyarat, maupun tulisan. Menurut Al-Khuli, bahasa adalah sistem suara yang terdiri atas simbol-simbol arbitrer (manasuka) yang digunakan oleh seseorang atau sekelompok orang untuk bertukar pikiran atau berbagi rasa. Melihat betapa pentingnya bahasa banyak diantara ilmuwan-ilmuwan yang tertarik untuk mendalami ilmu bahasa (linguistik) dimulai dari identitas maupun asal-usul bahasa itu sendiri. Bahkan bahasa 


\section{Idzi' Layyinati}

telah diakui oleh banyak orang sebagai identitas suatu bangsa.

Dalam dunia pendidikan, bahasa Arab menjadi salah satu mata pelajaran pokok yang diajarkan di sekolah atau madrasah khususnya yang berbasis islam seperti Madrasah Ibtidaiyah (MI), Madrasah Tsanawiyah (MTs), Madrasah Aliyah (MA), dan Perguruan Tinggi Agama Islam (PTAI). Alasan utama mengapa bahasa Arab menjadi penting untuk dipelajari adalah karena bagi umat Islam memahami dan mengamalkan isi Al-Qur'an, hadits serta kitab-kitab kajian Islam yang lain merupakan suatu kewajiban, sementara kitab-kitab tersebut ditulis menggunakan bahasa Arab. Jadi, tanpa mempelajarinya seseorang tidak dapat memahami dan mengkajinya secara baik dan benar.

Bahasa Arab adalah bahasa asing karena bukan merupakan bahasa pergaulan sehari-hari bagi warga negara Indonesia. Hal ini tertuang dalam Peraturan Menteri Agama RI Nomor 02 tahun 2008 tentang standar kompetensi lulusan dan standar isi pendidikan agama Islam dan bahasa Arab di madrasah.

Pembelajaran bahasa Arab di Madrasah Tsanawiyah (MTs) bukan lagi hal baru dalam dunia pendidikan di Indonesia. Karena secara umum, seluruh lembaga keagamaan sangat konsen terhadap peningkatan penguasaan bahasa bagi siswa-siswinya.

Selama ini dalam proses pembelajaran bahasa Arab, guru lebih banyak menggunakan metode yang masih bersifat konvensional, guru membacakan teks bacaan yang kemudian diikuti oleh siswa atau siswa membaca teks percakapan secara berpasangan, kemudian guru mengartikan teks bacaan, dan memberikan latihan soal. Dimana media yang sering digunakan adalah buku paket bahasa Arab dan papan tulis sehingga hal itu dapat membuat siswa bosan dan kurang minat untuk belajar karena proses pembelajaran yang kurang efektif dan akibatnya tercipta hasil belajar siswa yang kurang memuaskan. Oleh karena itu, perhatian dan motivasi orang tua di rumah juga sangat berperan untuk mendukung ketercapaiannya hasil belajar siswa di sekolah.

Dari studi kasus yang telah dilakukan sebelum penulis melalui proses wawancara pada guru mapel bahwa nilai hasil belajar bahasa Arab yang telah dicapai siswa kelas VII di MTs. Muhammadiyah 12 Palirangan pada Ujian Akhir Semester (UAS) ganjil sebelum dilakukan proses remidial, menunjukkan ketuntasan secara klasikal sebesar 36,18\% dan 63,82\%, tidak tuntas artinya hasil belajar bahasa Arab siswa kelas VII di MTs. Muhammadiyah 12 Palirangan masih tergolong rendah, karena ada $63,82 \%$ dari hasil belajar siswa yang nilainya masih dibawah 


\section{Pengaruh Penggunaan Media Gambar Untuk Meningkatkan Hasil Belajar Bahasa Arab}

KKM yaitu 75 .

Berangkat dari permasalahan pembelajaran bahasa Arab di atas, maka diperlukan adanya strategi pembelajaran yang dapat mendorong siswa untuk berperan aktif serta dapat menarik minat siswa dalam belajar bahasa Arab, salah satunya dengan penggunaan media pembelajaran. Media pembelajaran yang akan diterapkan dalam pembelajaran bahasa Arab ialah media gambar.

Berdasarkan latar belakang masalah di atas maka penulis merumuskan judul penelitian "Pengaruh Penggunaan Media Gambar untuk meningkatkan Hasil Belajar Bahasa Arab Siswa Kelas VII di MTs. Muhammadiyah 12 Palirangan”

\section{Rumusan Masalah}

Adapun rumusan masalah dari pembahasan ini, yaitu:

1. Bagaimana penggunaan media gambar terhadap hasil belajar bahasa Arab siswa Kelas VII di MTs. Muhammadiyah 12 Palirangan

2. Adakah pengaruh penggunaan media gambar terhadap hasil belajar bahasa Arab siswa Kelas VII di MTs. Muhammadiyah 12 Palirangan?

\section{Landasan teori}

\section{Hasil Belajar}

Hasil belajar merupakan hal yang dapat dipandang dari dua sisi yaitu sisi siswa dan sisi guru. Dari sisi siswa, hasil belajar merupakan tingkat perkembangan mental yang lebih baik bila dibandingkan pada saat sebelum belajar. Sedangkan dari sisi guru, hasil belajar adalah saat terselesaikannya bahan pelajaran.

Bukti bahwa seseorang telah belajar ialah terjadinya perubahan tingkah laku pada orang tersebut, misalnya dari tidak tahu menjadi tahu, dan dari tidak mengerti menjadi mengerti.

Howard Kingsley membagi 3 macam hasil belajar: 1) Keterampilan dan kebiasaan; 2) Pengetahuan dan pengertian; dan 3) Sikap dan cita-cita. Pendapat dari Howard Kingsley ini menunjukkan hasil perubahan dari semua proses belajar. Hasil belajar ini akan melekat terus pada diri siswa karena sudah menjadi bagian dalam kehidupan siswa tersebut.

Berdasarkan pengertian di atas, maka dapat disimpulkan bahwa hasil belajar adalah suatu penilaian akhir dari proses dan pengenalan yang telah dilakukan berulang-ulang. Serta akan tersimpan dalam jangka waktu lama atau bahkan tidak akan hilang selama-lamanya karena hasil 
belajar turut serta dalam membentuk pribadi individu yang selalu ingin mencapai hasil yang lebih baik lagi sehingga akan mengubah cara berpikir serta menghasilkan perilaku kerja yang lebih baik.

\section{Media Gambar}

Gambar adalah sesuatu yang diwujudkan secara visual dalam bentuk dua dimensi sebagai curahan atau pikiran. Gambar-gambar yang dapat digunakan sebagai media pembelajaran adalah lukisan, ilustrasi, iklan, kartun, potret, karikatur, dan gambar berseri. Kesemua itu dapat diperoleh dari majalah, buletin, kalender, dan media lainnya. Bahkan guru yang kreatif dapat membuatnya sendiri.

Media gambar adalah salah satu alat peraga yang efektif untuk menstimulasi anak dalam pembelajaran aspek berbicara. Sebelum media gambar digunakan sebagai sarana pembelajaran maka yang harus dipersiapkan adalah susunlah gambar dengan teratur supaya mudah digunakan pada waktunya. Hatihati menempel gambar supaya jangan salah tempel atau jatuh dan lain-lain, sehingga mengganggu perhatian anak. Guru melakukannya sambil menempelkan gambar yang sesuai dengan isi cerita pada papan media gambar.

Dalam dunia pendidikan, sering kali istilah alat bantu atau media komunikasi digunakan secara bergantian atau sebagai pengganti istilah media pendidikan (pembelajaran). Dengan penggunaan alat bantu berupa media komunikasi, hubungan komunikasi akan dapat berjalan dengan lancar dan dengan hasil yang maksimal.

Menurut Sudirman (1992: p.203) menyatakan bahwa: Media adalah segala alat fisik yang digunakan untuk menyampaikan isi materi pengajaran. Dalam pengertian ini, buku/modul, tape recorder, kaset, video recorder, camera video, televisi, radio, film, slide, foto, gambar, dan komputer adalah merupakan media pembelajaran. Media adalah bentukbentuk komunikasi baik yang tercetak maupun audio visual beserta peralatannya.

Di antara beberapa media pembelajaran media gambar adalah di antara media pembelajaran, media gambar adalah media yang paling umum dipakai. Hal ini dikarenakan siswa lebih menyukai gambar daripada tulisan, apalagi jika gambarnya dibuat dan disajikan sesuai dengan persyaratan gambar yang baik, sudah barang tentu akan menambah semangat siswa dalam mengikuti proses pembelajaran. Di bawah ini beberapa pengertian media gambar, diantaranya: 


\section{Pengaruh Penggunaan Media Gambar Untuk Meningkatkan Hasil Belajar Bahasa Arab}

1. Media gambar adalah segala sesuatu yang diwujudkan secara visual kedalam bentuk dua dimensi sebagai curahan ataupun pikiran yang bentuknya bermacam-macam seperti lukisan, potret, slide, film, strip, opaque projektor (Hamalik, 1994: p.95).

2. Media gambar adalah media yang paling umum dipakai, yang merupakan bahasan umum yang dapat dimengerti dan dinikmati dimana-mana (Sadiman, 1996: p.29).

3. Media gambar merupakan peniruan dari benda-benda dan pemandangan dalam hal bentuk, rupa, serta ukurannya relatif terhadap lingkungan (Soelarko, 1980: p.3).

Dari pengertian di atas dapat disimpulkan bahwa media gambar adalah perwujudan lambang dari hasil peniruan-peniruan benda-benda, pemandangan, curahan pikir atau ide-ide yang di visualisasikan kedalam bentuk dua dimensi. Pemanfaatan media pembelajaran ada dalam komponen metode mengajarsebagai salah satu upaya untuk mempertinggi proses interaksi gurusiswa dan interaksi siswa dengan lingkungan belajarnya. Oleh sebab itu fungsi utama dari media pembelajaran adalah sebagai alat bantu dalam pembelajaran

\section{Bahasa Arab}

Bahasa Arab adalah bahasa Al-Qur'an, bahasa dalam shalat, dalam beribadah, dan dalam mempelajari ilmu agama Islam tidak dapat dilepaskan dari bahasa Arab. Bahasa Arab juga merupakan alat utama budaya, terutama dalam sains, matematika, dan filsafat yang menyebabkan banyak bahasa Eropa turut meminjam banyak kosakata dari bahasa Arab. Menurut Al-Ghalayain, bahasa Arab adalah kalimat-kalimat yang dipergunakan oleh orang Arab untuk mengungkapkan tujuan-tujuan (pikiran dan perasaan) mereka. Sehingga bahasa Arab dikatakan sebagai bahasa wajib bagi umat Islam. Dikarenakan bahasa Arab telah memberi banyak kosakata kepada bangsa lain dari dunia Islam.

Bahasa Arab dan Al-Qur'an bagaikan dua sisi mata uang yang tidak dapat dipisahpisahkan antara satu dengan lainnya. Mempelajari bahasa Arab adalah syarat wajib untuk menguasai isi Al-Qur'an. Dan mempelajari bahasa Al-Qur'an berarti mempelajari bahasa Arab. Dengan demikian peranan bahasa Arab disamping sebagai alat komunikasi manusia sesamanya juga komunikasi manusia beriman kepada Allah, yang terwujud dalam bentuk shalat, doa-doa, dan sebagainya. Sebagaimana yang diterangkan dalam Al-Qur'an surat Yusuf ayat 2 yaitu:

Artinya : "Sesungguhnya Kami menurunkannya berupa Al-Qur'an berbahasa Arab, agar kamu mengerti" (QS: Yusuf. 2). 


\section{Karakteristik Bahasa Arab}

Bahasa Arab mempunyai ciri-ciri khusus yang tidak terdapat pada bahasa-bahasa lainnya. Kekhususannya ini menjadikan bahasa Arab sebagai bahasa yang fleksibel dan mempunyai elastisitas yang tinggi. Berikut ini adalah beberapa karakteristik bahasa Arab.

1) Memiliki gaya bahasa yang beragam.

2) Dapat diekspresikan secara lisan dan tulisan.

3) Memiliki sistem dan aturan yang spesifik.

4) Memiliki sifat arbiter (manasuka).

5) Selalu berkembang secara produktif dan kreatif.

6) Memiliki sistem tulisan yang khas.

7) Mempunyai struktur kata yang bisa berubah dan bereproduksi.

8) Memiliki sistem i'rab.

9) Sangat menekankan konformitas antar unsurnya.

10) Sangat kaya makna majasi.

11) Terjadi perbedaan antara makna kamus dengan makna yang dikehendaki dalam konteks kalimat tertentu.

\section{Tujuan Pembelajaran Bahasa Arab}

Tujuan utama dari pembelajaran bahasa Arab adalah menggali dan mengembangkan kemampuan peserta didik dalam menggunakan bahasa baik secara aktif (lisan) ataupun pasif (tulis). Sedangkan tujuan pembelajaran menurut Mahmud Yunus yang dikutip oleh Umi Hijriyah dapat diperinci sebagai berikut:

1) Agar paham dan mengerti apa-apa yang dibaca dalam shalat dengan pengertian yang mendalam.

2) Mampu membaca Al-Qur'an, sehingga dapat mengambil petunjuk dan pelajaran dari padanya.

3) Dapat belajar agama Islam dalam buku-buku yang banyak dikarang dalam bahasa Arab, seperti ilmu tafsir, fiqih, hadits, dan sebagainya.

4) Pandai dalam berbicara dan mengarang dalam bahasa Arab. 


\section{Pengaruh Penggunaan Media Gambar Untuk}

Meningkatkan Hasil Belajar Bahasa Arab

\section{Metode Penelitian}

\section{Teknik Pengumpulan Data}

Teknik pengumpulan data merupakan langkah yang paling strategis dalam penelitian, karena tujuan utama dalam penelitian adalah mendapatkan data, tanpa mengetahui teknik pengumpulan data, maka peneliti tidak akan mendapatkan data yang memenuhi standar data yang ditetapkan. Untuk mendapatkan data, peneliti menggunakan dua metode, yaitu:

\section{Observasi}

Observasi sebagai teknik pengumpulan data mempunyai ciri yang spesifik yaitu tidak terbatas pada orang, tetapi juga obyek-obyek alam yang lain. Sutrisno Hadi (1986) mengemukakan bahwa observasi merupakan suatu proses yang kompleks, suatu proses yang tersusun dari berbagai proses biologis dan psikologis. Dua di antara yang terpenting adalah proses-proses pengamatan dan ingatan.

\section{Tes}

Tes menurut Muchtar Buchori, yang dikutip oleh Suharsimi Arikunto, adalah suatu percobaan yang diadakan untuk mengetahui ada atau tidaknya hasil-hasil pelajaran tertentu pada seorang murid atau kelompok murid. Tes digunakan untuk mengukur kemampuan siswa. Dalam tes ini menggunakan pretest dan posttest.

\section{Teknik Analisis Data}

Analisis data merupakan kegiatan setelah data dari seluruh responden atau sumber data lain terkumpul.

\section{Uji Validitas Media}

Pada penggunaan media gambar, validitas ditunjukkan untuk menguji kelayakan media yang digunakan. Skor yang diperoleh dari lembar validasi dianalisis menggunakan skala Likert yang terdiri dari beberapa kategori sebagai berikut:

Tabel: Pedoman Skala Likert

\begin{tabular}{|l|l|l|}
\hline No & Skor & Keterangan \\
\hline 1 & 1 & Sangat Baik \\
\hline 2 & 2 & Baik \\
\hline
\end{tabular}




\begin{tabular}{|l|l|l|}
\hline No & Skor & Keterangan \\
\hline 3 & 3 & Cukup Naik \\
\hline 4 & 4 & Kurang Baik \\
\hline 5 & 5 & Sangat Kurang Baik \\
\hline
\end{tabular}

Sumber : Sugiyono (2017: p.136)

Analisis data dari lembar validasi diperoleh berdasarkan tanggapan para ahli media yang berupa skor dilakukan dengan menggunakan persentase :

$\mathrm{P}=\frac{\sum x}{\sum x_{i}} \mathrm{x} 100 \% \quad$ (Sumber: Arikunto, 2010: p.282)

Keterangan:

$\mathrm{P} \quad=$ Persentase validitas

$\sum x=$ Jumlah keseluruhan jawaban dalam seluruh item

$\sum x_{i}=$ Jumlah keseluruhan nilai ideal dalam seluruh item

$100=$ Konstanta

Kriteria validasi yang digunakan dalam validitas penelitian disajikan pada Tabel berikut:

Tabel: Tingkat Pencapaian dan Kualitas kelayakan

\begin{tabular}{|l|l|l|l|}
\hline No & $\begin{array}{l}\text { Tingkat } \\
\text { Pencapaian }\end{array}$ & Kualifikasi & Keterangan \\
\hline 1 & $81-100 \%$ & Sangat baik & $\begin{array}{l}\text { Sangat layak digunakan, } \\
\text { tidak perlu revisi }\end{array}$ \\
\hline 2 & $61-80 \%$ & Baik & $\begin{array}{l}\text { Layak digunakan, tidak } \\
\text { perlu direvisi }\end{array}$ \\
\hline 3 & $41-60 \%$ & Cukup baik & $\begin{array}{l}\text { Kurang layak digunakan, } \\
\text { perlu direvisi }\end{array}$ \\
\hline 4 & $21-40 \%$ & Kurang baik & $\begin{array}{l}\text { Tidak layak digunakan, } \\
\text { perlu direvisi }\end{array}$ \\
\hline 5 & $<20 \%$ & $\begin{array}{l}\text { Sangat kurang } \\
\text { baik }\end{array}$ & $\begin{array}{l}\text { Sangat tidak layak } \\
\text { digunakan, perlu direvisi }\end{array}$ \\
\hline
\end{tabular}

Sumber : Arikunto (2008: p.35) 


\section{Pengaruh Penggunaan Media Gambar Untuk Meningkatkan Hasil Belajar Bahasa Arab}

\section{Uji Persyaratan Analisis}

1) Uji Normalitas

Uji normalitas adalah suatu prosedur yang digunakan untuk mengetahui apakah data berasal dari populasi yang terdistribusi normal atau berada dalam sebaran normal. Dalam perhitungan uji normalitas ini peneliti menggunakan SPSS 20 for Windows dengan menggunakan metode One Sample Kolmogrov Sminov. Syarat suatu data dapat dikatakan berdistribusi normal adalah jika signifikansi $>0,05$.

2) Uji Homogenitas

Uji homogenitas adalah suatu prosedur uji statistik yang dimaksudkan untuk memperlihatkan bahwa dua atau lebih kelompok data sampel berasal dari populasi yang memiliki variansi yang sama. Uji homogenitas bertujuan untuk mencari tahu apakah dari beberapa kelompok data penelitian memiliki varians yang sama atau tidak. Dengan kata lain, homogenitas berarti bahwa himpunan data yang kita teliti memiliki karakteristik yang sama. Perhitungan uji homogenitas dalam penelitian ini dengan menggunakan uji Levene yang dilakukan menggunakan sofware SPSS 20 for Windows.

\section{Uji Hipotesis}

Salah satu teknik statistik yang kerap kali digunakan untuk mencari hubungan antara dua variabel atau lebih adalah teknik korelasi. Dua variabel yang hendak diselidiki hubungannya tersebut biasanya diberi simbol variabel $\mathrm{X}$ dan variabel $\mathrm{Y}$.

Bilamana kenaikan variabel $\mathrm{X}$ selalu disertai kenaikan variabel $\mathrm{Y}$, dan turunnya nilai variabel $\mathrm{X}$ juga selalu diikuti oleh turunnya nilai variabel $\mathrm{Y}$, maka hubungan yang seperti ini disebut hubungan yang positif. Akan tetapi sebailknya, bilamana nilai variabel $\mathrm{X}$ yang tinggi selalu disertai oleh variabel Y yang rendah nilainya, dan sebaliknya, bilamana nilai variabel X yang rendah selalu diikuti oleh nilai variabel Y yang tinggi, maka hubungan antara kedua variabel itu disebut hubungan yang negatif.

Teknik statistik yang digunakan dalam analisa korelasi pada penelitian ini menggunakan korelasi Pearson Product Moment, yatu salah satu teknik yang dikembangkan oleh Karl Pearson untuk menghitung koefisien korelasi. Kegunaan uji Pearson Product Moment atau analisis korelasi adalah untuk mengukur keeratan hubungan antara variabel bebas (X) dengan variabel terikat (Y) dan data berbentuk interval atau ratio. Rumus yang dikemukakan adalah sebagai berikut: 


$$
\mathrm{r}_{\mathrm{xy}}=\frac{\mathrm{n} \sum \mathrm{XY}-\left(\sum \mathrm{X}\right)\left(\sum \mathrm{Y}\right)}{\sqrt{\left[\mathrm{n} \sum \mathrm{X}^{2}-\left(\sum \mathrm{X}\right)^{2}\right]\left[\mathrm{n} \sum \mathrm{Y}^{2}-\left(\sum \mathrm{Y}\right)^{2}\right]}}
$$

keterangan :

$\mathrm{r}_{\mathrm{xy}}$ : Koefisien korelasi antara variabel $\mathrm{x}$ dan $\mathrm{y}$

$\sum \mathrm{xy} \quad$ : Jumlah perkalian antara variabel $\mathrm{x}$ dan $\mathrm{y}$

$\sum \mathrm{x}^{2}:$ Jumlah dari kuadrat nilai $\mathrm{x}$

$\sum \mathrm{y}^{2}:$ Jumlah dari kuadrat nilai $\mathrm{y}$

n: Jumlah sampel

Berikut ini adalah pedoman untuk memberikan interpretasi koefisien korelasi (nilai r).

Tabel: Interpretasi Koefisien Korelasi (Nilai r)

\begin{tabular}{|l|l|}
\hline Interval Koefisien & Tingkat Hubungan \\
\hline $0,00-0,199$ & Sangat rendah \\
$0,20-0,399$ & Rendah \\
$0,40-0,599$ & Sedang \\
$0,60-0,799$ & Kuat \\
$0,80-1,000$ & Sangat kuat \\
\hline
\end{tabular}

Sumber : Sugiyono (2017: p.257)

Untuk menguji signifikasi hubungan, yaitu apakah hubungan yang ditemukan itu berlaku untuk seluruh populasi, maka perlu diuji signifikansinya. Rumus uji signifikansi korelasi produt moment adalah sebagai berikut:

$$
t=\frac{r \sqrt{n-2}}{\sqrt{1-r^{2}}}
$$

Harga $t$ hitung yang diperoleh tersebut selanjutnya dibandingkan dengan harga $t$ tabel dengan taraf kesalahan tertentu (misal $\alpha=0,05$ atau $\alpha=0,01$ ) dan dengan $\mathrm{dk}=\mathrm{n}-2$. Ketentuannya bila $\mathrm{t}$ hitung $<\mathrm{t}$ tabel, maka $\mathrm{H}_{0}$ diterima dan Ha ditolak. Tetapi sebaliknya bila $\mathrm{t}$ hitung > t tabel, maka Ha diterima dan $\mathrm{H}_{0}$ ditolak.

Adapun uji signifikansi korelasi product moment secara praktis, yang tidak perlu dihitung, tetapi langsung dikonsultasikan pada tabel $\mathrm{r}$ product moment. Ketentuannya bila $\mathrm{r}$ hitung lebih kecil dari $\mathrm{r}$ tabel, maka $\mathrm{H}_{0}$ diterima dan Ha ditolak dan sebaliknya bila $\mathrm{r}$ hitung lebih besar dari $r$ tabel maka Ha diterima.

\section{Penyajian Data}

48 Volume 7 No. 1, 1 Maret 2021 
Data dalam penelitian ini diperoleh peneliti melalui observasi dan tes. Observasi digunakan oleh peneliti untuk mengamati langkah-langkah kegiatan pembelajaran yang berlangsung menggunakan media gambar. Sedangkan tes digunakan peneliti untuk mengetahui hasil belajar bahasa Arab siswa kelas VII MTs. Muhammadiyah 12 Palirangan ketika sebelum dan sesudah digunakannya media gambar dalam kegiatan pembelajaran. Berikut adalah data yang didapatkan dari hasil observasi dan tes:

\section{Data Hasil Observasi}

Adapun data hasil observasi yang dilakukan peneliti pada tanggal 8 Februari 2020 sampai dengan tanggal 7 Maret 2020, sebagaimana dapat dilihat pada Tabel berikut:

Tabel: Hasil Observasi Kegiatan Pembelajaran Menggunakan Media Gambar

\begin{tabular}{|c|c|c|c|c|c|}
\hline \multirow{2}{*}{$\begin{array}{l}\text { Aspek } \\
\text { Diamati }\end{array}$} & \multicolumn{5}{|c|}{ Kategori Skor } \\
\hline & 5 & 4 & 3 & 2 & 1 \\
\hline 1 & $\sqrt{ }$ & & & & \\
\hline 2 & & & $\sqrt{ }$ & & \\
\hline 3 & & & $\sqrt{ }$ & & \\
\hline 4 & $\sqrt{ }$ & & & & \\
\hline 5 & & $\sqrt{ }$ & & & \\
\hline 6 & $\sqrt{ }$ & & & & \\
\hline 7 & $\sqrt{ }$ & & & & \\
\hline 8 & $\sqrt{ }$ & & & & \\
\hline 9 & & $\sqrt{ }$ & & & \\
\hline 10 & $\sqrt{ }$ & & & & \\
\hline 11 & $\sqrt{ }$ & & & & \\
\hline 12 & & $\sqrt{ }$ & & & \\
\hline Jumlah Skor & 35 & 12 & 6 & - & - \\
\hline
\end{tabular}



Skor Maksimal 


$$
\begin{aligned}
\text { Persentase Nilai Perolehan } & =\frac{60}{60} \times 100 \% \\
& =88,33 \%
\end{aligned}
$$

Taraf keberhasilan yang ditetapkan yaitu :
a. $81 \%-100 \%$
: Sangat Baik
b. $61 \%-80 \%$
: Baik
c. $41 \%-60 \%$
: Cukup baik
d. $21 \%-40 \%$
: Kurang baik
e. $<20 \%$
: Sangat kurang baik

Berdasarkan perhitungan persentase nilai perolehan dalam observasi kegiatan pembelajaran menggunakan media gambar, maka diperoleh nilai secara klasikal sebesar 88,33\%. Dari hasil yang diperoleh dengan taraf keberhasilan yang ditetapkan, maka kesimpulannya adalah kegiatan pembelajaran menggunakan media gambat dinyatakan sangat baik.

\begin{tabular}{|c|c|c|c|}
\hline \multirow[b]{2}{*}{ Kegiatan } & \multirow[b]{2}{*}{ Indikator Kegiatan } & \multicolumn{2}{|c|}{ Terlaksana } \\
\hline & & $\begin{array}{l}\text { Ya } \\
\text { (Skor 1) }\end{array}$ & $\begin{array}{l}\text { Tidak } \\
\text { (Skor 0) }\end{array}$ \\
\hline \multirow{4}{*}{ Pendahuluan } & 1 & 1 & \\
\hline & 2 & 1 & \\
\hline & 3 & 1 & \\
\hline & 4 & 1 & \\
\hline \multirow[b]{5}{*}{ Inti } & 1 & 1 & \\
\hline & 2 & 1 & \\
\hline & 3 & 1 & \\
\hline & 4 & 1 & \\
\hline & 5 & 1 & \\
\hline
\end{tabular}

Tabel: Keterlaksanaan Kegiatan Pembelajaran dalam RPP (Rencana Pelaksanaan Pembelajaran) 


\begin{tabular}{|l|l|l|l|}
\hline \multirow{4}{*}{} & 6 & 1 & \\
\cline { 2 - 4 } & 7 & 1 & \\
\cline { 2 - 4 } & 8 & 1 & \\
\cline { 2 - 4 } & 9 & 1 & \\
\hline Penutup & 1 & 1 & - \\
\cline { 2 - 4 } & 2 & $\mathbf{1 5}$ & - \\
\hline Jumlah Skor & & 15 & \\
\hline
\end{tabular}

Jumlah Skor

Persentase Nilai Perolehan $==\times 100 \%$

Skor Maksimal

15

Persentase Nilai Perolehan $=-\times 100 \%$

15

$=100 \%$

Berdasarkan perhitungan persentase nilai perolehan keterlaksanaan kegiatan pembelajaran dalam RPP (Rencana Pelaksanaan Pembelajaran) yang dinilai oleh observer, maka diperoleh nilai sebesar $100 \%$. Artinya semua kegiatan pembelajaran yang tertuang dalam RPP (Rencana Pelaksanaan Pembelajaran) dapat dilaksanakan oleh peneliti dengan sangat baik.

\section{Data Hasil Tes}

Adapun daftar nilai hasil pretest dan posttest sebagaimana dapat dilihat pada Tabel berikut:

Tabel: Daftar nilai pretest dan posttest bahasa arab Siswa kelas VII di MTs.

Muhammadiyah 12 Palirangan

\begin{tabular}{|l|l|l|l|l|l|l|}
\hline No & \multirow{2}{*}{$\begin{array}{l}\text { Nama } \\
\text { Siswa }\end{array}$} & \multirow{2}{*}{ KKM } & \multicolumn{2}{|l|}{ Nilai } \\
\cline { 4 - 6 } & & & Pretest & Ketuntasan & Posttest & Ketuntasan \\
\hline 1 & A & 75 & 50 & Tidak tuntas & 60 & Tuntas \\
\hline 2 & B & 75 & 80 & Tuntas & 90 & Tuntas \\
\hline 3 & C & 75 & 70 & Tidak tuntas & 75 & Tuntas \\
\hline
\end{tabular}




\begin{tabular}{|l|l|l|l|l|l|l|}
\hline No & \multirow{2}{*}{$\begin{array}{l}\text { Nama } \\
\text { Siswa }\end{array}$} & \multirow{2}{*}{ KKM } & \multicolumn{2}{|l|}{ Nilai } & \multicolumn{2}{l}{$\mid$} \\
\cline { 5 - 7 } & & & Pretest & Ketuntasan & Posttest & Ketuntasan \\
\hline 4 & D & 75 & 90 & Tuntas & 100 & Tuntas \\
\hline 5 & E & 75 & 85 & Tuntas & 90 & Tuntas \\
\hline 6 & F & 75 & 75 & Tuntas & 80 & Tuntas \\
\hline 7 & G & 75 & 80 & Tuntas & 90 & Tuntas \\
\hline 8 & H & 75 & 65 & Tidak tuntas & 75 & Tuntas \\
\hline 9 & I & 75 & 65 & Tidak tuntas & 70 & Tidak tuntas \\
\hline 10 & J & 75 & 65 & Tidak tuntas & 70 & Tidak tuntas \\
\hline 11 & K & 75 & 80 & Tuntas & 90 & Tuntas \\
\hline 12 & L & 75 & 75 & Tuntas & 85 & Tuntas \\
\hline 13 & M & 75 & 70 & Tidak tuntas & 80 & Tuntas \\
\hline 14 & N & 75 & 70 & Tidak tuntas & 75 & Tuntas \\
\hline 15 & O & 75 & 90 & Tuntas & 100 & Tuntas \\
\hline 16 & P & 75 & 50 & Tidak tuntas & 55 & Tidak tuntas \\
\hline 17 & Q & 75 & 55 & Tidak tuntas & 65 & Tidak tuntas \\
\hline 18 & R & 75 & 70 & Tidak tuntas & 75 & Tuntas \\
\hline 19 & S & 75 & 75 & Tuntas & 85 & Tuntas \\
\hline 20 & T & 75 & 75 & Tuntas & 80 & Tuntas \\
\hline 21 & U & 75 & 65 & Tidak tuntas & 75 & Tuntas \\
\hline 22 & V & 75 & 65 & Tidak tuntas & 70 & Tidak tuntas \\
\hline 23 & W & 75 & 60 & Tidak tuntas & 70 & Tidak tuntas \\
\hline 24 & X & 75 & 70 & Tidak tuntas & 80 & Tuntas \\
\hline 25 & Y & 75 & 80 & Tuntas & 85 & Tuntas \\
\hline 26 & Z & 75 & 90 & Tuntas & 100 & Tuntas \\
\hline Jumlah & & $\mathbf{1 8 6 5}$ & & $\mathbf{7 1 0 7 0}$ & \\
\hline Rata-rata & & & & & \\
\hline
\end{tabular}




\begin{tabular}{|c|c|c|c|c|c|c|}
\hline \multirow[t]{2}{*}{ No } & \multirow{2}{*}{$\begin{array}{l}\text { Nama } \\
\text { Siswa }\end{array}$} & \multirow{2}{*}{ KKM } & \multicolumn{4}{|l|}{ Nilai } \\
\hline & & & Pretest & Ketuntasan & Posttest & Ketuntasan \\
\hline \multicolumn{2}{|c|}{ Tuntas } & & & $\begin{array}{l}12 \text { Siswa } \\
(46,15 \%)\end{array}$ & & $\begin{array}{l}21 \text { siswa } \\
(80,76 \%)\end{array}$ \\
\hline \multicolumn{2}{|c|}{\begin{tabular}{|l} 
Tidak Tuntas \\
\end{tabular}} & & & $\begin{array}{l}14 \text { Siswa } \\
(53,84 \%)\end{array}$ & & $\begin{array}{l}5 \text { siswa } \\
(19,23 \%)\end{array}$ \\
\hline
\end{tabular}

Berdasarkan Tabel di atas, peneliti memperoleh nilai pretest hasil belajar bahasa Arab yang telah dicapai siswa kelas VII MTs. Muhammadiyah 12 Palirangan menunjukkan 12 siswa yang tuntas secara klasikal dengan persentase $46,15 \%$ dan 14 siswa yang tidak tuntas secara klasikal dengan persentase 53,84\%, artinya dari data pretest tersebut lebih banyak siswa yang tidak tuntas dalam mapel bahasa arab hal tersebut dikarenakan sisw masih belum banyak yang memahami materi tersebut.

Berdasarkan Tabel di atas, peneliti memperoleh nilai posttest hasil belajar bahasa Arab yang telah dicapai siswa kelas VII MTs. Muhammadiyah 12 Palirangan menunjukkan 21 siswa yang tuntas secara klasikal dengan persentase $80,86 \%$ dan 5 siswa yang tidak tuntas secara klasikal dengan persentase $19,14 \%$, artinya terdapat peningkatan hasil belajar bahasa Arab siswa kelas VII MTs. Muhammadiyah 12 Palirangan bila dibandingkan dengan hasil pretest sebelum proses pembelajaran menggunakan media gambar dilakukan.

\section{Analisis Data}

\section{Uji Validitas Media}

Berikut adalah data validasi media dari tiga validator sebagaimana dapat dilihat pada Tabel berikut ini:

Tabel: Hasil Validasi Ahli Media

\begin{tabular}{|l|l|l|l|l|l|}
\hline \multirow{2}{*}{ Validator } & \multicolumn{3}{|l|}{ Aspek Penilaian } & Jumlah \\
\cline { 2 - 6 } & 1 & 2 & 3 & 4 & \\
\hline 1 & 15 & 18 & 4 & 10 & 47 \\
\hline 2 & 15 & 17 & 3 & 8 & 43 \\
\hline
\end{tabular}




\begin{tabular}{|l|l|l|l|l|l|}
\hline \multirow{2}{*}{ Validator } & \multicolumn{3}{|l|}{ Aspek Penilaian } & Jumlah \\
\cline { 2 - 6 } & 1 & 2 & 3 & 4 & \\
\hline 3 & 14 & 18 & 4 & 6 & 42 \\
\hline Jumlah per aspek & 44 & 53 & 11 & 24 & 132 \\
\hline Rata-rata & 14,66 & 17,66 & 3,66 & 8 & 44 \\
\hline Persentase (\%) & $97,77 \%$ & $88,33 \%$ & $73,33 \%$ & $80 \%$ & $88 \%$ \\
\hline
\end{tabular}

Keterangan Aspek Penilaian:

1 : Penulisan kata, teks atau bahasa (3 kriteria)

2 : Desain (4 kriteria)

3 : Pewarnaan (1 kriteria)

4 : Bahan pembuatan (2 kriteria)

Tabel: Tingkat Pencapaian dan Kualitas kelayakan

\begin{tabular}{|l|l|l|l|}
\hline No & $\begin{array}{l}\text { Tingkat } \\
\text { Pencapaian }\end{array}$ & Kualifikasi & Keterangan \\
\hline 1 & $81-100 \%$ & Sangat baik & $\begin{array}{l}\text { Sangat layak digunakan, tidak } \\
\text { perlu revisi }\end{array}$ \\
\hline 2 & $61-80 \%$ & Baik & $\begin{array}{l}\text { Layak digunakan, tidak perlu } \\
\text { direvisi }\end{array}$ \\
\hline 3 & $41-60 \%$ & Cukup baik & $\begin{array}{l}\text { Kurang layak digunakan, perlu } \\
\text { direvisi }\end{array}$ \\
\hline 4 & $21-40 \%$ & Kurang baik & $\begin{array}{l}\text { Tidak layak digunakan, perlu } \\
\text { direvisi }\end{array}$ \\
\hline 5 & $<20 \%$ & Sangat kurang baik & $\begin{array}{l}\text { Sangat tidak layak digunakan, } \\
\text { perlu direvisi }\end{array}$ \\
\hline
\end{tabular}

Sumber : Arikunto (2008: p.35)

Berdasarkan pada Tabel di atas, hasil validasi media secara keseluruhan dari tiga validator yaitu sebesar 88\%. Dari hasil yang diperoleh pada dengan kriteria validasi yang telah ditentukan pada Tabel 4.8, maka kesimpulannya adalah media gambar yang digunakan pada pembelajaran bahasa Arab dinyatakan sangat valid, dalam artian sangat layak digunakan dan tidak perlu dilakukan revisi. 


\section{Pengaruh Penggunaan Media Gambar Untuk Meningkatkan Hasil Belajar Bahasa Arab}

\section{Uji Persyaratan Analisis dan Uji Hipotesis}

a. Uji Persyaratan Analisis

Berdasarkan hasil penelitian yang diperoleh, maka data akan diolah dengan uji hipotesis. Namun sebelumnya, terlebih dahulu akan dilakukan pengujian prasyarat analisis data, yaitu uji normalitas dan uji homogenitas.

1) Uji Normalitas

Adapun uji normalitas dilakukan yaitu untuk mengetahui apakah sampel yang diteliti berdistribusi normal atau tidak. Dalam perhitungan uji normalitas ini peneliti menggunakan sofware SPSS 20 for Windows.

Adapun analisis dan kriteria pengujian hipotesis sebagai berikut:

a) Hipotesis yang diajukan adalah:

$\mathrm{H}_{0}$ : Sampel berasal dari populasi yang berdistribusi normal

$\mathrm{Ha}$ : Sampel tidak berasal dari populasi yang berdistribusi normal

b) Kriteria pengujian yaitu :

(1) Jika signifikansi $>0,05$, maka $\mathrm{H}_{0}$ diterima

(2) Jika signifikansi < 0,05, maka $\mathrm{H}_{0}$ ditolak

Hasil uji normalitas data pretest dan posttest sebagaimana yang disajikan dalam Tabel berikut:

Tabel: Hasil Uji Normalitas Data Pretest dan Posttest

\begin{tabular}{|c|c|c|c|}
\hline & & pretest & posttest \\
\hline $\begin{array}{l}\text { N } \\
\text { Normal Parameters }{ }^{\mathrm{a}, \mathrm{b}} \\
\text { Most Extreme Differences } \\
\text { Kolmogorov-Smirnov Z } \\
\text { Asymp. Sig. (2-tailed) }\end{array}$ & $\begin{array}{l}\text { Mean } \\
\text { Std. Deviation } \\
\text { Absolute } \\
\text { Positive } \\
\text { Negative }\end{array}$ & $\begin{array}{l}47 \\
74,1489 \\
10,90070 \\
, 109 \\
, 076 \\
-, 109 \\
, 744 \\
, 637 \\
\end{array}$ & $\begin{array}{l}47 \\
81,7021 \\
10,94833 \\
, 108 \\
, 091 \\
-, 108 \\
, 739 \\
, 646\end{array}$ \\
\hline
\end{tabular}

Output pada Tabel di atas, menjelaskan tentang hasil uji normalitas dengan metode One Sample Kolmogrov Sminov. Untuk pengambilan keputusan apakah data berdistribusi normal atau tidak maka cukup membaca pada nilai signifikansi (Asymp Sig 2-tailed). Dapat diketahui bahwa nilai signifikansi untuk data pretest sebesar 0,637 dan data posttest sebesar 0,646. Dalam hal ini perolehan nilai signifikansi lebih besar dari taraf signifikansi $(0,637>0,05$ dan $0,646>0,05)$, maka $\mathrm{H}_{0}$ diterima. 
Dengan demikian dapat disimpulkan bahwa data pretest dan posttest berdistribusi normal.

2) Uji Homogenitas

Setelah data sampel penelitian dinyatakan berdistribusi normal, selanjutnya mencari nilai homogenitas varians pretest dan posttest. Uji homogenitas dilakukan untuk mengetahui apakah data tersebut memiliki tingkat varians data yang sama atau tidak. Kriteria pengujian adalah jika signifikansi lebih dari 0,05 maka data sampel dapat dikatakan homogen dan sebaliknya, jika nilai signifikansi kurang dari 0,05 maka data sampel dapat dikatakan tidak homogen.

Dalam perhitungan uji homogenitas ini peneliti menggunakan software SPSS 20 for Windows. Hasil uji homogenitas data pretest dan posttest sebagaimana yang disajikan dalam Tabel berikut:

Tabel: Hasil Uji Homogenitas Data Pretest dan Posttest

\begin{tabular}{|l|l|l|l|}
\hline Levene Statistic & df1 & df2 & Sig. \\
\hline, 007 & 1 & 92 &, 933 \\
\hline
\end{tabular}

Output pada Tabel di atas, dapat dilihat bahwa nilai signifikansi adalah sebesar 0,933. Dalam hal ini perolehan nilai signifikansi lebih besar dari taraf signifikansi $(0,933>0,05)$. Dengan demikian dapat disimpulkan bahwa data sampel memiliki varians yang homogen.

b. Uji Hipotesis

Setelah dilakukan uji persyaratan analisis data, kemudian dilakukan pengujian hipotesis dengan rmenggunakan uji korelasi product moment yang bertujuan untuk mengukur keeratan hubungan antara variabel X (penggunaan media flashcard) dengan variabel Y (hasil belajar bahasa Arab).

Dalam perhitungan uji korelasi product moment ini peneliti menggunakan software SPSS 20 for Windows. Hasil uji korelasi product moment sebagaimana yang disajikan dalam Tabel berikut: 
Tabel: Hasil Uji Korelasi Product Moment

\section{Correlations}

\begin{tabular}{|c|c|c|c|}
\hline & & $x$ & $y$ \\
\hline \multirow[t]{3}{*}{$x$} & Pearson Correlation & 1 & .977 \\
\hline & Sig. (2-tailed) & & .000 \\
\hline & $\mathrm{N}$ & 26 & 26 \\
\hline \multirow[t]{3}{*}{$y$} & Pearson Correlation & $.977^{\star \pi}$ & 1 \\
\hline & Sig. (2-tailed) & .000 & \\
\hline & $\mathrm{N}$ & 26 & 26 \\
\hline
\end{tabular}

\section{Tabel: Pedoman Untuk Memberikan Interpretasi Koefisien Korelasi}

\begin{tabular}{|l|l|}
\hline Interval Koefisien & Tingkat Hubungan \\
\hline $0,00-0,199$ & Sangat rendah \\
$0,20-0,399$ & Rendah \\
$0,40-0,599$ & Sedang \\
$0,60-0,799$ & Kuat \\
$0,80-1,000$ & Sangat kuat \\
\hline
\end{tabular}

\section{Sumber : Sugiyono (2017: p.257)}

Interpretasi output SPSS pada Tabel di atas, koefisien korelasi yang ditemukan sebesar 0,977 termasuk pada kategori sangat kuat berdasarkan Tabel 4.12 tersebut. Jadi, terdapat hubungan yang sangat kuat antara penggunaan media gambar terhadap hasil belajar bahasa Arab siswa kelas VII MTs. Muhammadiyah 12 Palirangan tahun pelajaran 2019/2020. Hubungan tersebut baru berlaku untuk sampel yang 26 siswa tersebut. Untuk menguji signifikansi hubungan, yaitu apakah hubungan yang ditemukan itu berlaku untuk seluruh populasi yang berjumlah 97 siswa, maka perlu diuji signifikansinya.

Uji signifikansi korelasi product moment dalam penelitian ini dilakukan secara praktis, yang tidak perlu dihitung, tetapi langsung dikonsultasikan pada tabel r product moment. Dari $\mathrm{r}$ tabel product moment, bahwa $\mathrm{n}=26$, taraf kesalahan 5\%, maka diperoleh harga $\mathrm{r}$ tabel sebesar 0,404. Ketentuannya bila $\mathrm{r}$ hitung lebih kecil dari $\mathrm{r}$ tabel, maka $\mathrm{H}_{0}$ diterima dan Ha ditolak dan sebaliknya bila $r$ hitung lebih besar dari $r$ tabel ( $r$ hitung $>r$ tabel ) maka $\mathrm{H}_{0}$ ditolak dan Ha diterima. Ternyata, $\mathrm{r}$ hitung $(0,977)$ lebih besar dari $\mathrm{r}$ tabel $(0,404)$. Dengan demikian $\mathrm{H}_{0}$ ditolak dan Ha diterima. Jadi kesimpulannya koefisien 
korelasi antara penggunaan media gambar terhadap hasil belajar bahasa Arab sebesar 0,977 adalah signifikan berdasarkan hasil koefisien tersebut juga dapat dipahami bahwa korelasinya bersifat positif, artinya koefisien tersebut dapat berlaku pada populasi dimana sampel yang 26 siswa diambil.

\section{Kesimpulan}

Berdasarkan hasil penelitian dan pembahasan tentang "Pengaruh Penggunaan Media Gambar untuk meningkatkan Hasil Belajar Bahasa Arab Siswa Kelas VII di MTs. Muhammadiyah 12 Palirangan" peneliti dapat mengambil kesimpulan sebagai berikut:

1. Perbedaan hasil belajar siswa sebelum dan sesudah menggunakan media gambar dapat dilihat dari rata-rata hasil pre-test dan post-test siswa. Dimana rata-rata nilai hasil pre-test adalah 71,73sedangkan rata-rata nilai hasil post-test adalah 79,61. Dari data tersebut dapat dilihat bahwa nilai hasil pre-test lebih rendah dibandingkan dengan nilai post-test, sehingga dapat diartikan bahwa terdapat perbedaan hasil belajar siswa sebelum dan sesudah menggunakan media gambar dalam proses pembelajaran.

I. Presentase dari kriteria ketuntasan dari nilai hasil pre-test adalah $46,15 \%$, sedangkan dari nilai hasil post-test adalah $80,76 \%$. Dari data tersebut sudah bisa diketahui bahwa menggunakan media gambar dapat mempengaruhi hasil belajar siswa. Kemudian dari pengujian hipotesis yang menggunakan uji Corelasi Product Moment dan uji Paired Sample T-test dengan bantuan software SPSS 20 pada bagian sig (2-tailed) diketahui sebesar $0,000<0,05$ Ketentuannya bila $r$ hitung lebih kecil dari $r$ tabel, maka $\mathrm{H}_{0}$ diterima dan Ha ditolak dan sebaliknya bila $r$ hitung lebih besar dari $r$ tabel ( $r$ hitung $>\mathrm{r}$ tabel $)$ maka $\mathrm{H}_{0}$ ditolak dan Ha diterima. Ternyata, $\mathrm{r}$ hitung $(0,977)$ lebih besar dari $r$ tabel $(0,404)$. Dengan demikian $\mathrm{H}_{0}$ ditolak dan Ha diterima. Sebagaimana dasar pengambilan keputusan dalam uji Corelasi Product Moment dan pedoman keputusan berdasarkan nilai probabelitas dapat diambil kesimpulan bahwa $\mathrm{H}_{0}$ ditolak dan $\mathrm{H}_{\mathrm{a}}$ diterima. Artinya, media gambar dapat mempengaruhi peningkatan hasil belajar pada materi bahasa arab kelas VII di MTs. Muhammadiyah 12 Palirangan. 


\section{Pengaruh Penggunaan Media Gambar Untuk}

Meningkatkan Hasil Belajar Bahasa Arab

\section{Daftar Rujukan}

Acep Hermawan, 2011. Metodologi Pembelajaran Bahasa Arab. Bandung: PT Remaja Rosdakarya

Aris Shoimin, 68 2014. Model Pembelajaran Inovatif dalam Kurikulum 2013. Yogyakarta: ARRUZZ MEDIA

Dimyati dan Mudjiono, 2006. Belajar dan Pembelajaran. Jakarta: Rineka Cipta

Rudi Susilana dan Cepi Riyana, 2011. Media Pembelajaran. Bandung: CV Wacana Prima

Nana Sudjana, 2005. Penilaian Hasil Proses Belajar Mengajar. Bandung: Remaja Rosdakarya

Nuryadi, dkk. 2017. Dasar-Dasar Statistik Penelitian. Yogyakarta: Sibuku Media

Oemar Hamalik, 2008. Proses Belajar Mengajar. Jakarta: Bumi Aksara

Santoso, Subhan Adi, 2020. Media Pembelajaran Pendidikan Agama Islam Era Industri 4.0. Yogyakarta: Deepublish

Sugiyono, 2017. Metode Penelitian Pendidikan (Pendekatan Kuantitatif, Kualitatif dan R\&D). Bandung: Penerbit Alfabeta

Sutrisno Hadi, 2004. Statistik (jilid 2). Yogyakarta: Penerbit Andi

Ulin Nuha, 2016. Ragam Metodologi \& Media Pembelajaran Bahasa Arab. Yogyakarta: DIVA Press 
Idzi' Layyinati

60 Volume 7 No. 1, 1 Maret 2021 